'Highland' and 'Lowland' zones ; a different set of nineteen 'physiographic and structural units' based on the same zones; and a suggestion in Fig. 234 that, from the point of view of population density there are three divisions which "correspond roughly with industrial, good agricultural, and poor agricultural tracts". With all these ingredients could there not be a consideration of geographical regions? Or is geography to concern itself only with the distribution of different facts? Now that the authors have drawn upon the specialists, one is confident that they could undertake this formidable task. If they do they could then call the next edition of this book "The Geography of the British Isles".

\title{
Progress in Enzyme Chemistry
}

\section{Ergebnisse der Enzymforschung}

Herausgegeben von F. F. Nord und R. Weidenhagen. Band 7. Pp. xiv + 437. (Leipzig : Akademische Verlagsgesellschaft m.b.H., 1938.) 34 gold marks.

TTHIS year's volume follows the now well1 known lines: it is substantially larger, perhaps indicating the intense interest in the subject. With one exception, the articles are in English or German; that on sulfatases by $\mathrm{Cl}$. Fromageot is in French. As usual they cover selected sections of experimental activity which can conveniently be summarized at this moment.

Pride of place may be claimed for M. L. Anson's brief note on crystalline carboxypeptidase, a long name for a pancreatic enzyme which, however, is explicit as to the action it performs. The enzymes are now largely regarded as proteins, so that it is a question of finding out the right conditions for their isolation, when the further investigation of their structure can go hand in hand with that of the proteins. Interposing, the view may be expressed that this particular problem of protein structure is not being attacked with all the forces that its importance indicates. Anson stresses the extreme difference in the protein properties of the various enzyme proteins, which have so far contributed to prevent their isolation by standardized systematic procedures. It is clear now that ordinary cells contain a multiplicity of proteins and that the specific properties of these serve to control many of the chemical reactions which take place in living cells. The control exercised by varying the stereochemical configuration of such a relatively simple substance as glucose has been often stressed; obviously with the complex proteins the possibilities of variation are infinitely more numerous.

Next in significance may be placed the story by $H$. Raistrick of some aspects of the biochemistry of the lower fungi, which indicate certain relationships in structure between the large number of mould metabolic products. The interesting conclusion is expressed that one of the first stages in the life of most fungi is that of synthesis of a complex polysaccharide from the nutrient available in the same way that starch is a primary product of synthesis in the green plant. At a later stage this polysaccharide is broken down in a variety of ways, giving rise to the characteristic products of the individual race. Renewed interest is at once attached to such polysaccharides and to their structure-four new ones are described.

The question of the relation of specificity to chemical structure continues to promote investigation. It is the basis of a well-compiled report on immunochemistry and its relation to enzymes by J. Marrack, as well as the article on emulsin by B Helferich, who has long been the protagonist for ascribing a wide range of activity to this enzyme rather than regarding it as a mixture. His arguments are not altogether convincing. A new point of importance here is the hint that the tryptophane unit in emulsin has a role in its activity.

The knowledge of the group of ferments which breaks down the nucleic acids has progressed to a satisfactory stage and it is valuable to have a crisp summary of these nucleases compiled by H. Bredereck.

Among the more difficult articles is one from the pen of Otto Warburg on the chemical constitution of the enzymes, a question to which an answer is anxiously awaited. The treatment is largely mathematical and concerns the relation between the metallic prosthetic group and the conjugated protein for certain oxidizing and reducing enzymes.

The technical article this year concerns the part played by enzymes in the tanning industry ; it is written by $F$. Schneider and covers a wide field in forty pages. Of technical interest also is a summary of the biochemistry of acetic acid bacteria which indicates all the more recent observations.

The examples selected suffice to show the wide range of subjects covered and the utility of the "Ergebnisse" in these days when it has become impossible to keep up with the original literature. E. F. A. 